\title{
Short communication: The effect of dry period duration and dietary energy density in early lactation on the rennet gelation properties of milk
}

\author{
S. T. Butler, ${ }^{* 1}$ M. A. de Feu, ${ }^{*}$ B. O'Brien, ${ }^{*}$ T. P. Guinee,† and J. J. Murphy* \\ ${ }^{*}$ Teagasc, Moorepark Dairy Production Research Centre, and \\ †Teagasc, Moorepark Food Research Centre, Fermoy, Co. Cork, Ireland
}

\begin{abstract}
This study was carried out to examine the effects of decreasing the dry period (DP) duration and altering the energy density of the diet during early lactation on the rheological characteristics of milk. Forty mature Holstein-Friesian cows were used in a completely randomized design with a $2 \times 2$ factorial arrangement of treatments. Cows were randomly assigned to 1 of 2 dry period treatments and 1 of 2 nutritional treatments. The DP treatments were continuous milking $(\mathrm{CM})$ or an 8-wk standard dry period (SDP), and the nutritional treatments were a standard energy diet (SE) or a high energy diet (HE). Actual DP lengths were $6.3 \pm 1.7 \mathrm{~d}$ and $62.1 \pm 1.9 \mathrm{~d}$ for cows on the CM and SDP treatments, respectively. Milk samples were collected at 2, 6 , and $10 \mathrm{wk}$ postpartum. The concentrations of fat, protein, and lactose were determined in each sample. The rennet gelation properties were measured at $31^{\circ} \mathrm{C}$ using dynamic low-amplitude strain oscillatory rheometry. The following parameters were obtained from the resultant elastic shear modulus $\left(\mathrm{G}^{\prime}\right)$ : gelation time, maximum curd firming rate, and gel strength. Reducing the DP duration from 62 to $6 \mathrm{~d}$ resulted in increases in milk protein concentration ( 31.8 vs. $34.7 \mathrm{~g} / \mathrm{kg})$, maximum curd firming rate (2.58 vs. $3.60 \mathrm{~Pa} / \mathrm{min})$, and gel strength (69.4 vs. $90.5 \mathrm{~Pa})$. Increasing the dietary energy density decreased percentage milk fat (43.1 vs. $37.7 \mathrm{~g} / \mathrm{kg}$ ) but otherwise had no effect. Gel strength was correlated with maximum curd firming rate $(\mathrm{r}=$ 0.99), and both variables were correlated with milk protein concentration $(\mathrm{r}=0.71$ and $\mathrm{r}=0.73$, respectively). The results indicate that decreasing the duration of the DP increased milk protein concentration and improved the rennet gelation properties of milk, but that dietary energy density had little effect.
\end{abstract}

Key words: milk, dry period duration, dietary energy density, rennet gelation

Received August 17, 2009.

Accepted October 27, 2009

${ }^{1}$ Corresponding author: stephen.butler@teagasc.ie
Decreasing the duration of the dry period between lactations has recently gained considerable attention in the management of dairy cows (Annen et al., 2004a; Grummer and Rastani, 2004). Omitting the dry period improves energy balance in early lactation, with a consequent reduction in BCS loss (Rastani et al., 2005). This is achieved through the combined effects of higher dietary energy intake and decreased milk energy output (Rastani et al., 2005), although administration of bST prevents the decrease in milk output in multiparous cows (Annen et al., 2004b). It is well documented that severe negative energy balance and excessive body condition loss in early lactation are risk factors for fatty liver, ketosis, and compromised reproductive performance (Butler and Smith, 1989; Drackley, 1999). Thus, decreasing the dry period duration may have potentially important benefits for dairy cow health and longevity. The effect of decreasing dry period duration on milk processability has not been examined, but a previous report indicated that a decrease in dry period duration increased milk protein concentration in the subsequent lactation (Rastani et al., 2005). This change in protein concentration is expected to have marked implications for the rennet gelation of milk and the manufacturing efficiency and composition of cheese (Guinee et al., 2006).

Rennet gelation of milk is a central step in the manufacture of many cheese varieties such as Cheddar, Mozzarella, and Gouda. The resultant gel is subjected to several operations (e.g., cutting, cooking, acidification, pressing, and salting) that differ in degree with cheese variety and result in the formation of cheese (curd). The rennet gelation characteristics (curd firming rate, set-to-cut time, firmness) of the milk have marked effects on cheese composition (e.g., moisture) and percentage recovery of fat from milk to cheese, and, hence, manufacturing efficiency and quality (Banks et al., 1981, 1984; Lelievre and Gilles, 1982; Mayes and Sutherland, 1989; O'Brien et al., 1999; Guinee et al., 2005). Consequently, the rennet gelation characteristics are a valuable indicator of the suitability of milk for cheese manufacture. However, the rennet gelation of milk is also influenced by numerous factors other 
Table 1. Mean milk composition and rennet gelation results during wk 2, 6, and 10 postpartum ${ }^{1}$

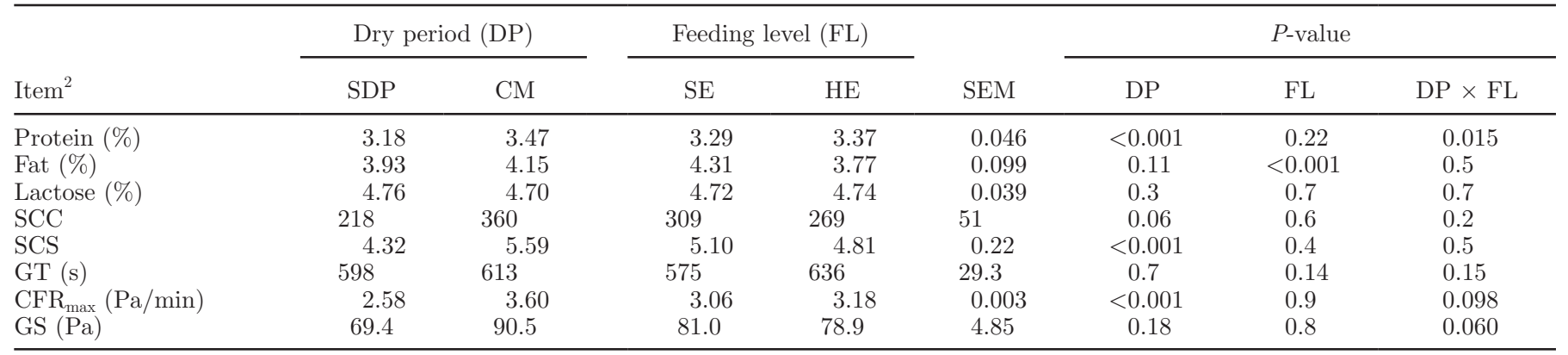

${ }^{1} \mathrm{SDP}=$ standard dry period; $\mathrm{CM}=$ continuous milking; $\mathrm{SE}=$ standard energy diet; HE = high energy diet.

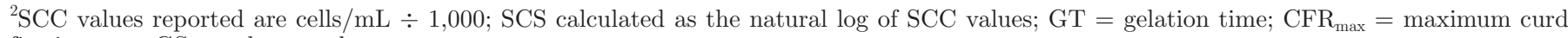
firming rate; GS = gel strength

than protein including other compositional factors, $\mathrm{pH}$, SCC, and calcium level (Fox et al., 2000). The objective of the current study was to evaluate the effects of dry period duration, dietary energy density, and their interaction on the composition and rennet gelation of milk.

Forty multiparous Holstein-Friesian dairy cows were used in a completely randomized $2 \times 2$ factorial design. The 2 factors examined in the study were dry period duration and dietary energy density. For dry period duration, cows were assigned to either continuous milking (CM) or a 8-wk standard dry period (SDP). Cows on the CM treatment were dried off when daily milk yield was $<2 \mathrm{~kg} /$ d. Actual dry period lengths were $6.3 \pm 1.7$ $\mathrm{d}$ and $62.1 \pm 1.9 \mathrm{~d}$ for cows on the CM treatment and the SDP treatment, respectively. Dietary energy density treatments consisted of either standard energy (SE) or high energy (HE) diets. The HE diet was formulated to have a greater voluntary DMI and a higher energy density compared with the SE diet [1.02 vs. 0.96 unité fourragère lait (UFL)/kg of DM; 1 UFL is equivalent to $1 \mathrm{~kg}$ of standard air-dried barley]. Full details of the study design, management of the experimental animals, and effects on milk production have been reported previously (de Feu et al., 2009).

Milk samples were collected at wk 2, 6, and 10 postpartum from all cows at the afternoon milking for composition, SCC, and rheology analysis. Samples were pooled when cows within treatment at a common week postpartum were sampled in the same week; this resulted in the number of cows contributing to each composite milk sample for rennet gelation analysis ranging from 1 to 4; each dry period duration and feeding level treatment combination had 7 replicates at wk 2, 6, and 10 postpartum. Milk samples were stored overnight at $4^{\circ} \mathrm{C}$, and analysis was carried out on the day after sample collection. An aliquot of each pooled milk sample was analyzed for fat, protein and lactose concentrations by near-infrared reflectance spectroscopy (Milkoscan 605, Foss Electric, Hillerød, Denmark), and SCC was measured by laser-based flow cytometry (Somacount 300, Bentley Instruments Inc., Chaska, MN).

The rennet gelation properties were measured using low-amplitude strain oscillation (Advanced Rheometer ER550, TA Instruments, Crawley, UK). The pH of 100 $\mathrm{mL}$ of milk was standardized to 6.55 at room temperature. The temperature of the milk was then brought to $31^{\circ} \mathrm{C}$ by immersing the milk sample in a water bath, and the $\mathrm{pH}$ was readjusted to 6.55 if necessary. Rennet (Chymax Plus, Pfizer Inc., Milwaukee, WI), diluted to 1:20 with deionized water, was added to milk at a level of $0.18 \mathrm{~mL}$ of undiluted rennet per liter of milk. The sample was subjected to a low-amplitude shear strain of 0.025 at a frequency of $1 \mathrm{~Hz}$ and the elastic shear modulus $\left(\mathbf{G}^{\prime}\right)$ was measured continuously as a function of time (Guinee et al., 1997). The following variables were calculated from the resultant $\mathrm{G}^{\prime}$-time profiles: gelation time (GT), defined as the time in seconds for $\mathrm{G}^{\prime}$ to reach a value $\geq 0.2 \mathrm{~Pa}$; maximum curd firming rate $\left(\mathbf{C F R}_{\text {max }}\right)$, defined as the maximum slope of the $\mathrm{G}^{\prime}$-time curve; and gel strength (GS) defined as the $\mathrm{G}^{\prime}$ value at $50 \mathrm{~min}$.

Data were analyzed as a factorial design using the MIXED procedure of SAS (SAS Institute Inc., Cary, NC). Fixed effects in the model included dry period length, feeding level, lactation week, and all possible interactions, and sample was included as a random effect. Preplanned contrasts between SE and HE at each dry period length, and between SDP and CM at each feeding level were carried out using the ESTIMATE statement. Correlation analysis (PROC CORR) was undertaken to test for correlations between rennet gelation characteristics and milk composition results.

The mean values for milk composition and rennet gelation characteristics for the different treatments are summarized in Table 1 and Figure 1. The mean 

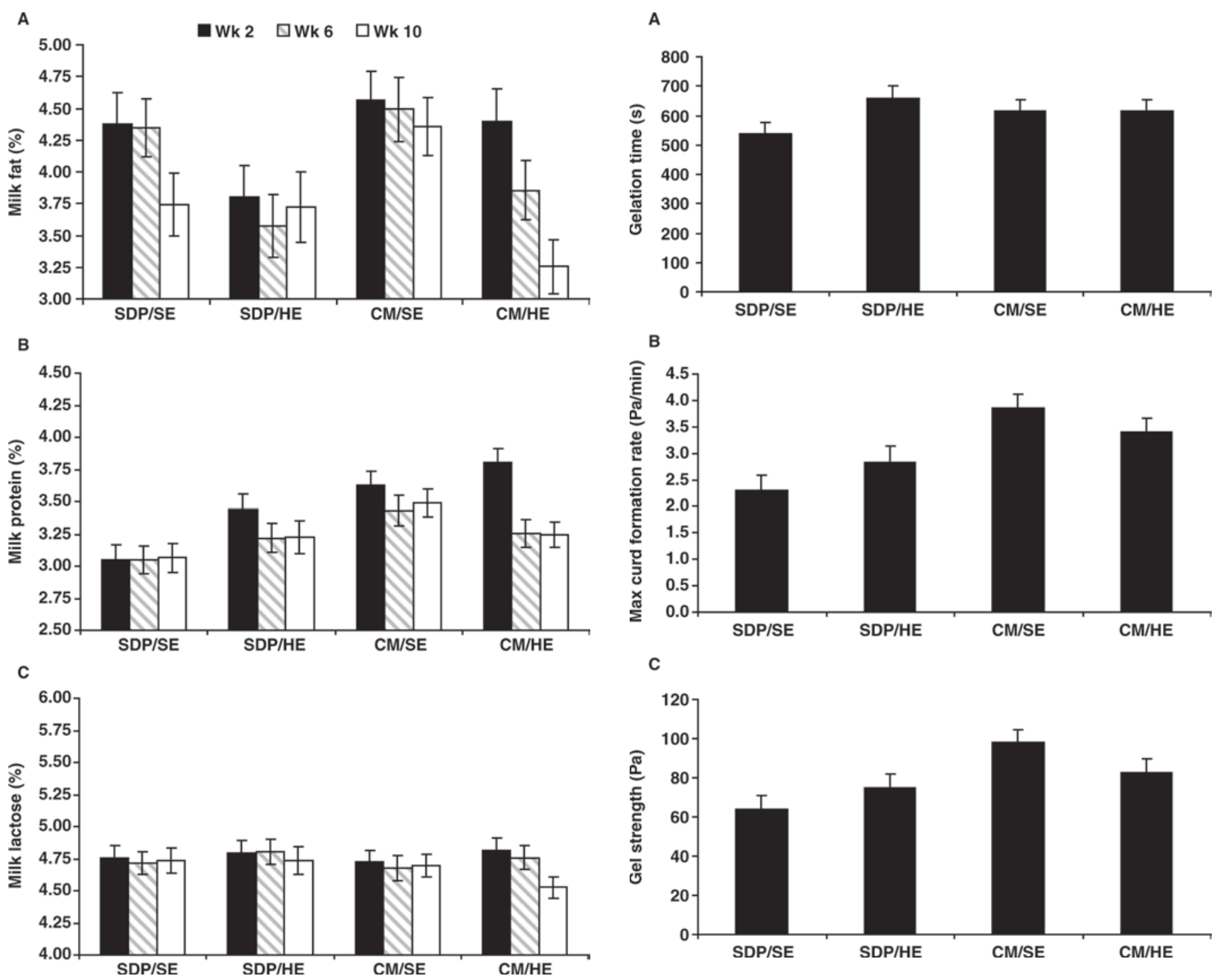

Figure 1. Effects of dry period duration and feeding level on milk composition during wk 2,6 , and 10 postpartum on milk fat, protein and lactose. A) Milk fat concentrations were not affected by decreasing dry period duration $(P>0.1)$ but were decreased by increasing dietary energy density $(P<0.001)$. The effect of lactation week was also significant $(P=0.015)$. B) Milk protein concentration was increased by decreasing dry period duration $(P<0.001)$ but dietary energy density did not have a significant effect $(P>0.2)$. A significant interaction between dry period duration and dietary energy density was observed $(P$ $=0.016)$, and lactation week was also a significant effect $(P=0.006)$. C) Milk lactose concentrations were not affected by dry period duration, dietary energy density, lactation week, or any interaction term (all $P>0.3$ ). SDP $=$ standard dry period; $\mathrm{CM}=$ continuous milking; $\mathrm{SE}=$ standard energy diet; $\mathrm{HE}=$ high energy diet.

milk fat content of the cows on the HE diet was $12.5 \%$ lower than that of the cows on the SE diet (4.31 vs. $3.77 \% ; P<0.001)$, a result that concurs with the welldocumented milk-fat-depressing effects of high energy diets (Bauman and Griinari, 2003). An interaction $(P$ $=0.016)$ between dry period duration and feeding level

Figure 2. Effects of dry period duration and feeding level on the rennet gelation characteristics of milk. Milk samples were collected at wk 2, 6, and 10 postpartum. The fixed effect "lactation week" was not significant for any of the 3 rheological variables, and therefore overall means are presented. A) Mean gelation time was not affected by either dry period duration or dietary energy density $(P>0.1)$. B) Maximum curd firming rate was increased $(P<0.001)$ by decreasing dry period duration, but dietary energy density did not have a significant effect $(P>0.8)$. The interaction between dry period length and dietary energy density tended to be significant $(P=0.10)$. C) Gel strength was increased $(P<0.01)$ by decreasing dry period duration, but dietary energy density did not have a significant effect $(P>0.7)$. The interaction between dry period length and dietary energy density tended to be significant $(P=0.06)$. SDP $=$ standard dry period; $\mathrm{CM}=$ continuous milking; $\mathrm{SE}=$ standard energy diet; $\mathrm{HE}=$ high energy diet.

was observed for the concentration of milk protein (Figure 1$)$, whereby the HE diet increased $(P=0.013)$ milk protein concentration for SDP cows, but had no effect for $\mathrm{CM}$ cows $(P>0.3)$. Values for $\mathrm{CFR}_{\max }$ and GS were increased in milk from CM cows compared with SDP cows but were not affected by dietary energy density 
(Table 1, Figure 2). However, for both $\mathrm{CFR}_{\max }$ and GS, the interaction between dry period duration and feeding level came close to significance $(P=0.1$ and $P=$ 0.06 , respectively). In general, the effects of each factor and their interaction on $\mathrm{CFR}_{\max }$ and GS were mirrored by the effects on milk protein content. Neither dry period duration nor feeding level had significant effects on GT, but post hoc data analysis revealed that milk from cows on the SDP treatment fed the SE diet had a shorter GT than cows fed the HE diet (537 vs. $659 \mathrm{~s}, P$ $<0.05$; Figure 2).

Maximum curd firming rate was highly correlated with GS $(\mathrm{r}=0.99 ; P<0.001)$, and both variables were correlated with milk protein concentration $(\mathrm{r}=0.73$ and $\mathrm{r}=0.71$, respectively; both $P<0.001$ ). Weak but significant correlations were also observed between milk fat concentration and $\mathrm{CFR}_{\max }(\mathrm{r}=0.37, P=0.001)$ and GS ( $\mathrm{r}=0.35, P=0.002)$. However, this observation is likely explained by the fact that milk fat concentration was correlated with milk protein concentration $(\mathrm{r}=$ $0.33, P=0.004)$, rather than milk fat concentration having any direct positive effects on $\mathrm{CFR}_{\max }$ or GS. Somatic cell count was not influenced by treatment; mean SCC values for the dry period and feeding level treatments were within the range previously reported by O'Brien et al. (2006). Rennet gelation properties of the milk samples were not affected by SCC, in agreement with the report by O'Brien et al. (2006).

The higher protein content in milk from cows on the continuous milking treatment is beneficial in terms of its potential to increase cheese yield. All other factors being equal, Cheddar cheese yield increases by approximately 0.25 to $0.30 \mathrm{~kg} / 100 \mathrm{~kg}$ of milk for every $0.1 \mathrm{~g} / 100$ $\mathrm{g}$ increase in milk protein in the range 3.0 to $4.5 \mathrm{~g} / 100$ $\mathrm{g}$, while retaining the protein to fat ratio constant at 0.96 (Guinee et al., 1994, 1996, 2006). Moreover, the increase in milk protein and associated improvement in the rennet gelation characteristics of CM treatment milk has implications for cheesemaking efficiency; for example, percentage recovery of components such as moisture, fat, and protein. These effects can be particularly manifest in large modern cheese plants (e.g., processing >1-2 ML of milk per day). In these operations, coagulant and starter culture are added to milk on a volume basis (rather than on a protein or casein basis), the rennet gel tends to be cut on the basis of time rather than on gel firmness or gel firming rate, and other steps such as speed and duration of the cut program are fixed. With such practices, a more rapid gelation and higher curd firming rate minimize the risk of the curd being cut when underset. Associated defects, such as shattering of curd particles during cutting and early stages of stirring, smaller curd particles, higher losses of moisture and fat, and lower cheesemaking efficiency are also less likely to be encountered. Nevertheless, the use of appropriate manufacturing protocols (e.g., gelation temperature, gel firmness at cutting, cut programs) enable satisfactory cheesemaking efficiencies to be achieved across the range of protein levels observed in the current study.

In conclusion, continuous milking significantly enhanced the rennet gelation characteristics of milk (i.e., maximum curd firming rate, gel strength), an effect attributable mainly to the higher milk protein content. In contrast, increasing dietary energy density did not affect the rennet gelation characteristics. The results indicate that shortening the duration of the dry period could have beneficial effects on the processability of milk.

\section{ACKNOWLEDGMENTS}

The authors thank Jonathon Kenneally for collection of milk samples and Norann Galvin for her skillful laboratory assistance (both of Teagasc, Moorepark, Fermoy, Co. Cork, Ireland). National Development Plan funding is gratefully acknowledged.

\section{REFERENCES}

Annen, E. L., R. J. Collier, M. A. McGuire, and J. L. Vicini. 2004a. Effects of dry period length on milk yield and mammary epithelial cells. J. Dairy Sci. 87(E. Suppl.):E66-E76.

Annen, E. L., R. J. Collier, M. A. McGuire, J. L. Vicini, J. M. Ballam, and M. J. Lormore. 2004b. Effect of modified dry period lengths and bovine somatotropin on yield and composition of milk from dairy cows. J. Dairy Sci. 87:3746-3761.

Banks, J. M., W. Banks, D. D. Muir, and A. G. Wilson. 1981. Cheese yield: Composition does matter. Dairy Ind. Int. 46:15-22.

Banks, J. M., D. D. Muir, and A. Y. Tamime. 1984. A comparison of the quality of Cheddar cheese produced from seasonal and standardized milk. J. Soc. Dairy Technol. 37:88-92.

Bauman, D. E., and J. M. Griinari. 2003. Nutritional regulation of milk fat synthesis. Annu. Rev. Nutr. 23:203-227.

Butler, W. R., and R. D. Smith. 1989. Interrelationships between energy balance and postpartum reproductive function in dairy cattle. J. Dairy Sci. 72:767-783.

de Feu, M. A., A. C. O. Evans, P. Lonergan, and S. T. Butler. 2009. The effect of dry period duration and dietary energy density on milk production, bioenergetic status and postpartum ovarian function in Holstein-Friesian dairy cows. J. Dairy Sci. 92:6011-6022.

Drackley, J. K. 1999. Biology of dairy cows during the transition period: The final frontier? J. Dairy Sci. 82:2259-2273.

Fox, P. F., T. P. Guinee, T. M. Cogan, and P. L. H. McSweeney. 2000. Fundamentals of Cheese Science. Aspen Publishers Inc., Gaithersburg, MD.

Grummer, R. R., and R. R. Rastani. 2004. Why reevaluate dry period length? J. Dairy Sci. 87(E. Suppl.):E77-E85.

Guinee, T. P., C. B. Gorry, D. J. O'Callaghan, B. T. O'Kennedy, N. O'Brien, and M. A. Fenelon. 1997. The effects of composition and some processing treatments on the rennet coagulation properties of milk. Int. J. Dairy Technol. 50:99-106.

Guinee, T. P., J. Kelly, and D. J. O'Callaghan. 2005. Cheesemaking efficiency. End of Project Report 2003, MFRC No. 46. Teagasc, Oakpark Carlow, Ireland.

Guinee, T. P., D. J. O'Callaghan, E. O. Mulholland, and D. Harrington. 1996. Milk protein standardization by ultrafiltration for Cheddar cheese manufacture. J. Dairy Res. 63:281-293. 
Guinee, T. P., B. T. O'Kennedy, and P. M. Kelly. 2006. Effect of milk protein standardization using different methods on the composition and yields of Cheddar cheese. J. Dairy Sci. 89:468-482.

Guinee, T. P., P. D. Pudja, and E. O. Mulholland. 1994. Effect of milk protein standardization, by ultrafiltration, on the manufacture, composition and maturation of Cheddar cheese. J. Dairy Res. $61: 117-131$.

Lelievre, J., and J. Gilles. 1982. The relationship between the grade (product value) and composition of young commercial Cheddar cheese. N.Z. J. Dairy Sci. Technol. 17:69-75.

Mayes, J. J., and B. J. Sutherland. 1989. Further notes on coagulum firmness and yield in Cheddar cheese manufacture. Aust. J. Dairy Technol. 44:47-48.
O'Brien, B., T. P. Guinee, A. Kelly, and P. Joyce. 2006. Processability of late-lactation milk from a spring-calved dairy herd. Aust. J. Dairy Technol. 61:3-7.

O'Brien, B., R. Mehra, J. F. Connolly, and D. Harrington. 1999 Seasonal variation in the composition of Irish manufacturing and retail milks. 1. Chemical composition and renneting properties. Ir. J. Agric. Food Res. 38:53-64.

Rastani, R. R., R. R. Grummer, S. J. Bertics, A. Gumen, M. C. Wiltbank, D. G. Mashek, and M. C. Schwab. 2005. Reducing dry period length to simplify feeding transition cows: milk production, energy balance, and metabolic profiles. J. Dairy Sci. 88:10041014 